\title{
Implementation of Halal Product Assurance in the Pharmaceutical Sector in Indonesia
}

\author{
Resti Dian Luthviati ${ }^{{ }^{*}}$ Suviwat Jenvitchuwong ${ }^{b}$ \\ a Demographic and Civil Registration Study Program, Universitas Sebelas Maret, Indonesia \\ b Faculty of Law, Thammasat University, Bangkok, Thailand. \\ *Corresponding author: restidianl@staff.uns.ac.id
}

\section{ARTICLE INFO}

\section{Article history}

Received: August 10, 2021

Revised: August 28, 2021

Accepted: August 30, 2021

\section{Keywords}

Products;

Pharmaceutical;

Halal;

Legal Protection;

\section{ABSTRACT}

The goal of this research is to determine and assess the implementation of halal certification for the pharmaceutical business in accordance with Law Number 33 of 2014 on Halal Product Assurance, as well as the variables that hinder and support its implementation. The impact of the JPH Law on the process value chain and supply chain of drugs and vaccines results in a total change in the pharmaceutical industry, including changes in ingredients resulting in reprocessing of quality, safety, and efficacy, changes in the distribution process, addition of personnel or staff, decreased economic capacity of the industry due to increased production costs, and there is a decrease in the industry's economic capacity due to increased costs of production. The halal status of a product has become a must-have for all consumers, particularly Muslims. Some parties, particularly the pharmaceutical business, continue to oppose to the existence of Law No. 33 of 2014 concerning Halal Product Guarantee. The supply of special facilities, such as rooms, equipment, and human resources, will significantly raise costs, resulting in higher drug prices and a reduction in people's access to the items they truly require for health care. Currently, the pharmaceutical sector must import 95 percent or more of its raw materials, totaling 150,000 items, in order to make about 30,000 different types of pharmaceuticals in the country.

This is an open-access article under the CC-BY 4.0 license.
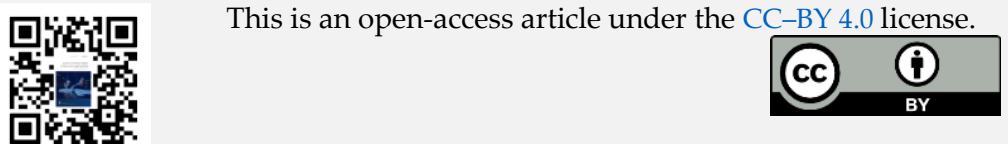

\section{Introduction}

Indonesia is the initiator of the formation of the World Halal Food Council. The construction was motivated by the halal certification standard carried out by the Institute for the Study of Food, Drugs, and Cosmetics of the Indonesian Ulema Council (LPPOM MUI), which is one of the world's references. ${ }^{1}$ This step did not

${ }^{1}$ Norazlina Abdul Aziz and Siti Sarah Sulaiman, 'Role of the Local Authority in Issuing License for Halal Certified Premise in the City of Shah Alam', Procedia - Social and Behavioral Sciences, 121.September 2012 (2014), 133-43 https://doi.org/10.1016/j.sbspro.2014.01.1115 
support the legislators in Indonesia, so that the already well-established halal system was not implemented properly. This can be seen from the very minimal number of pharmaceutical products that get halal certification labels. ${ }^{2}$ The Indonesian Ulema Council stated that only three vaccine products hold halal certification labels, namely for meningitis vaccination, namely Menveo Meningococcal Novartis product and Mevac Acyw135 product of tian yuan. The last vaccine is a diarrhea vaccine for toddlers with the brand Rotarix made by the drug factory GSK. ${ }^{3}$

Pharmaceuticals, in addition to vaccinations, are a major concern; just 34 drugs are halal certified out of the 30 thousand types of medicines registered with the LPPOM and circulating in the community. The Indonesian government has responded by enacting rules and regulations governing food, medicine, and cosmetic products. However, it cannot be employed as a strong legal framework, and it has not been able to bind product halalness to producers (commercial actors) or provide consumers with guarantees. This is why, despite the need for halal product assurances, which is vital and urgent, especially in terms of consumer safety in global trade, there is no guarantee of legal certainty that governs halal products. ${ }^{4}$

The distribution of information from the Food and Drug Supervisory Agency (BPOM) Mataram that food supplements eaten by the public for a long time included pork deoxyribonucleic acid caused an outrage on Indonesian social media in January 2018. (DNA). Viostin Ds and Enzyplex are two products that have gained distribution permissions from the BPOM of the Republic of Indonesia. The emergence of products that pass LPPOM without information on pork content raises concerns about how haphazard the Indonesian government's halal certification standards are. ${ }^{5}$

In Indonesia, the rules and regulations guarantee that every customer has the right to acquire information about any product. Every customer has the right to clear and honest information on the terms and guarantees of goods and services, as stated in Article 4, letter C of the Consumer Protection Act. The right to this information is crucial because if a producer offers enough information about a product, including halal information, the customer can choose the best goods and services for them based on their Shari'a beliefs. To safeguard Muslim customers

${ }^{2}$ Wilma Taverne-Veldhuizen and others, 'Effect of Hydrogenation of Palm Oil Products Spiked with Octachlorodibenzo-p-Dioxin on Dioxin Congener Profiles and Toxic Equivalent Levels', Food Control, 132.August 2021 (2022), 108546 https://doi.org/10.1016/j.foodcont.2021.108546

${ }^{3}$ Zakiah Samori and Noorsalwati Sabtu, 'Developing Halal Standard for Malaysian Hotel Industry: An Exploratory Study', Procedia - Social and Behavioral Sciences, 121.September 2012 (2014), 144-57 https://doi.org/10.1016/j.sbspro.2014.01.1116

${ }^{4}$ Dwi Edi Wibowo, 'Ewuh Pakewuh Cultural Reconstruction to Equal Consumer Protection', Jurnal Bestuur, 8.1 (2020), 1-8<https://doi.org/10.20961/bestuur.41395>.

5Tommy Shih and Yen Yu Huang, 'A Case Study on Technology Entrepreneurship Education at a Taiwanese Research University', Asia Pacific Management Review, 22.4 (2017), 202-11 https://doi.org/10.1016/j.apmrv.2017.07.009 
against non-halal items, business actors providing goods and or services for trade are required to provide transparent and honest information that the products traded are halal products by including the MUI halal certificate emblem, according to Article 4 letter c. ${ }^{6}$

On October 17, 2014, the Halal Product Assurance Law (Law No.33 of 2014) was signed into law. Still, pharmaceutical firms have objected to halal certification for the pharmaceutical items they create, therefore its implementation has been rocky. The halal certification procedure for pharmaceutical goods is hampered by a number of problems, including a scarcity of halal-certified raw materials and barriers to halal management in the Indonesian pharmaceutical industry. In addition to the raw materials, it is critical to look at information about the manufacturing process when determining the halalness of a product. ${ }^{7}$ It's just that this isn't something that can be communicated through the packaging. It may be claimed that their position was vaguely being gradually raised in such a situation. This condition is unquestionably adverse to religious teachings' implementation. ${ }^{8}$

Muslims have the right to obtain knowledge, including assurance, about whether a product is halal or haram, regardless of whether they feel the necessity. Especially in a country like Indonesia, where the majority of the population is Muslim. On the one hand, halal and haram concerns should be viewed as people's rights, with the state's commitment to uphold them on the other. As a result, the Indonesian government responds to the public's desire for halal products by enacting Law Number 33 of 2014 on Halal Product Guarantee, which is a manifestation of the government of the Republic of Indonesia's obligation to provide protection and guarantees regarding the halalness of products consumed and used by the public. ${ }^{9}$

Article 4 of Law Number 33 of 2014 states, "products that enter, circulate, and are traded in the territory of Indonesia must be certified Halal." Law number 33 of 2014 concerning guarantees for halal products is present as a solution to protect the people of Indonesia. Indonesia, with a majority Muslim population, must always use Halal products. Law Number 33 of 2014 concerning Halal Product Guarantee then requires all products circulating in Indonesia, whether produced domestically or are imported goods, to obtain a halal certificate. From the contents of article 4, it can be concluded that the imposition of rules regarding halal

${ }^{6}$ Vloreen Nity Mathew, Ardiana Mazwa Raudah binti Amir Abdullah, and Siti Nurazizah binti Mohamad Ismail, 'Acceptance on Halal Food among Non-Muslim Consumers', Procedia - Social and Behavioral Sciences, 121 (2014), 262-71 https://doi.org/10.1016/j.sbspro.2014.01.1127

${ }^{7}$ Chiratus Ratanamaneichat and others, 'A Guideline for Reinforcing Water Based Community's Economic Strength', Procedia - Social and Behavioral Sciences, 88 (2013), 173-78 https://doi.org/10.1016/j.sbspro.2013.08.493

8Pattawan Narjaikaew, 'Alternative Conceptions of Primary School Teachers of Science about Force and Motion', Procedia - Social and Behavioral Sciences, 88 (2013), 250-57 https://doi.org/10.1016/j.sbspro.2013.08.503

'Liana Endah Susanti, 'Economic Law Creation Beautiful Global Indonesia', Bestuur, 7.1 (2020), 47 https://doi.org/10.20961/bestuur.v7i1.42701 
product guarantees has not only an impact on domestic products but also products from abroad or imported products. ${ }^{10}$

In addition, the era of free trade also opens vast opportunities for the export of products in our country, including processed foods, medicines, and cosmetics. These export opportunities must be utilized as well as possible by entrepreneurs. Thus, the chance to enter the international market is increasingly open. However, to enter the market, entrepreneurs must meet several international standards, including halal labeling, discussed in the Codex Alimentarius Commission. (CAC) Halal certificates should also be required for medicinal products circulating in Indonesia. Drugs circulating in Indonesia have many raw materials, both from Indonesia and abroad. Suppose all-natural materials must have a Halal certificate. In that case, every drug entrepreneur must conduct a lot of research to determine whether the raw materials are halal or not, especially for raw materials originating from abroad. Based on data recorded by the association of Indonesian pharmaceutical entrepreneurs, information is obtained that $95 \%$ of pharmaceutical raw materials are imported from abroad. The obligation to have a halal certificate will cause pharmaceutical entrepreneurs to incur higher costs in conducting inspections of raw materials. In this case, the certification body will also experience difficulties in verifying the raw materials. Cosmetic entrepreneurs will also face the problems mentioned above. ${ }^{11}$

Halal certification has an increasingly important role in increasing demand for global halal products (LPPOM MUI). Moreover, Indonesia, as a Muslim-majority country, providing halal products as an obligation. Thus the market opportunity for halal and good food is extensive and promising, so this should be a business opportunity for the people of Indonesia. According to Elvy Even die, the LPPOMMUI DIY Partnership in the General Islamic Economy Stadium with the theme "Development of the Halal Industry in DIY After the Enforcement of the Halal Product Guarantee Act," Law No. 33 of 2014 concerning the Guarantee of Halal Products has not been able to run because many provisions in the Act are still unclear, such as the Ministerial Authority. LPPOM-MUI DIY has no permanent workers, yet they are still university employees. BPJPH has yet to be founded, and it should be responsible with carrying out all of the provisions for the execution of halal product assurances. ${ }^{12}$

All products that enter, circulate, or are exchanged in Indonesia's territory must be certified halal, according to Article 4 of Law Number 33 of 2014. However, the

\footnotetext{
${ }^{10}$ Lego Karjoko, Zaidah Nur Rosidah, and I. Gusti Ayu Kutut Rachmi Handayani, 'Refleksi Paradigma Ilmu Pengetahuan Bagi Pembangunan Hukum Pengadaan Tanah Lego', Bestuur, 7.2 (2019), 1-14 https://doi.org/https://doi.org/10.20961/bestuur.v7i1.42694

${ }^{11 Z a i d a h ~ N u r ~ R o s i d a h, ~ ' C o h e r e n c e ~ o f ~ t h e ~ R u l e s ~ o f ~ S h a r i a ~ A g a i n s t ~ P a n c a s i l a ', ~ B e s t u u r, ~} 8.1$ (2020), 40 https://doi.org/10.20961/bestuur.v8i1.42723

${ }^{12}$ Nurfaika Ishak, Rahmad Ramadhan Hasibuan, and Tri Suhendra Arbani, 'Bureaucratic and Political Collaboration Towards a Good Governance System', Bestuur, 8.1 (2020), 19 https://doi.org/10.20961/bestuur.v8i1.42922
} 
community's products are not entirely guaranteed to be halal. Halal is more than just a certification; it's only a minor part of it. Halal also refers to how the procedure can ensure the industry's halal status. The food and beverage industry plays a vital role, and the majority of these businesses are small and family-run. The company's commitment to Muslim customers includes producing halal items. Companies in Indonesia must get a MUI Halal Certificate to assure consumers that their products are halal. ${ }^{13}$

The public, as consumers, are more fully entrusting the supervision of halal product guarantees to the countries they consider the most authorized to provide sanctions and legal pressure if deemed necessary. Halal assurance standards are a type of promise that products are halal, and they can be classified as high-quality or hygienic. Essentially, the existence of halal product guarantees stems from the noble principle that the general public has the right to receive accurate, clear, and comprehensive information about the quantity and quality of the items they consume. As a result, there are behaviors such as expiry, the use of non-intended colours, and the use of dangerous ingredients. This clause, however, contradicts Article 26 paragraph (1) of the JPH Law, which says that business actors that manufacture items using prohibited ingredients are excused from seeking for a halal certificate. ${ }^{14}$

\section{Results and Discussion}

\subsection{Implementation of Legal Protection for Halal Product Guarantees for Consumers}

Product qualities, according to Grolleau and BenAbid, are separated into three categories: search characteristics, experience characteristics, and credence features. Consumers' efforts to detect, test, assess, and validate items are used to divide characteristics. Product features that can be examined, tested, validated, and recognized reliably and quickly by customers before they buy the product in question are known as search characteristics. Consumers can test the nature of a product like this individually and manually using their five senses. ${ }^{15}$

Consumers can search and test products properly and effectively on their own, which is why it's called search characteristics. Consumers can analyze, test, validate, and detect product attributes accurately and effectively after purchasing

${ }^{13}$ Najella Zubaidi, Regy Gusti Pratama, and Sholahuddin Al-Fatih, 'Legal Perspective on Effectiveness of Pre-Work Cards for Indonesian People', Bestuur, 8.1 (2020), 9 https://doi.org/10.20961/bestuur.v8i1.42722

${ }^{14}$ Chaisak Chitcharoen and others, 'A Model to Investigate the Influence of Channel, Perceived Web Quality, Brand Awareness, Perceived Quality on After-Sales Service of the All-in-One Office Products', Procedia - Social and Behavioral Sciences, $88 \quad$ (2013), 8-12 https://doi.org/10.1016/j.sbspro.2013.08.475

${ }^{15}$ Aiedah Abdul Khalek, 'Young Consumers' Attitude towards Halal Food Outlets and JAKIM's Halal Certification in Malaysia', Procedia - Social and Behavioral Sciences, 121.September 2012 (2014), 26-34 https://doi.org/10.1016/j.sbspro.2014.01.1105 
and using the product in issue for a (specified) short length of time compared to the overall use of the product over its lifetime. ${ }^{16}$ This indicates that the ability of consumers to test, assess, and validate items is based on their own consumption experience. Because consumer experience may be used to test product understanding, these are referred to as experience characteristics. ${ }^{17}$

Credence Features are product characteristics that cannot be reliably and efficiently evaluated, tested, validated, or detected by consumers, even after they have purchased and used the product in question. Consumers are unable to test, assess, and validate the product because they lack technical skills, despite the fact that it has been widely utilized. Because customers lack the technical knowledge to differentiate, test, and assess impacts, consumers rely on their "trust" and confidence that the items given by manufacturers are correct and as they should be, which are referred to as credence qualities. ${ }^{18}$ In products having search features that may be evaluated through appearance, sight, and aroma, such as apple color, Grolleau and Ben Abid present an example: Characteristics of experience-based products, such as apple flavor, may be evaluated by taste, which means that consumers can learn after purchasing and using the product. Finally, consumers' credibility features, such as nutritious composition, cannot be examined and tested by consumers. It could, for example, imply that consumers are unaware of it even after they have consumed the product. ${ }^{19}$

Assume the product qualities are similar to and associated with halal items. In that instance, the following are some examples: The origin and authenticity of products with search criteria, specifically products that are still intact, are known, and their halalness is known with certainty. Plants that have not been processed at all, such as rice and guava, are an example (guava). Also, an animal that is still alive and intact, such as an ox, chicken, or goat that is still alive and intact. Based on their visibility and understanding in products like these, consumers may search, test, and certify halal directly, correctly, and efficiently. ${ }^{20}$

${ }^{16}$ Haslizatul Mohamed Hanum and others, 'Using Topic Analysis for Querying Halal Information on Malay Documents', Procedia - Social and Behavioral Sciences, 121.September 2012 (2014), 214-22 https://doi.org/10.1016/j.sbspro.2014.01.1122

${ }^{17}$ Penpak Chauyraksa, 'The Satisfaction on General Affairs Service of Electrical Engineering Faculty of Industrial and Technology, Rajamangala University of Technology Isan', Procedia - Social and Behavioral Sciences, 88 (2013), 149-53 https://doi.org/10.1016/j.sbspro.2013.08.490

18 Supatra Wanpen, 'The Relationship between Learning Styles and the Social Network Use of Tertiary Level Students', Procedia - Social and Behavioral Sciences, 88 (2013), 334-39 https://doi.org/10.1016/j.sbspro.2013.08.514

${ }^{19}$ Veeraphat Krittanathip and others, 'The Reduction of Inventory and Warehouse Costs for Thai Traditional Wholesale Businesses of Consumer Products', Procedia - Social and Behavioral Sciences, 88 (2013), 142-48 https://doi.org/10.1016/j.sbspro.2013.08.489

${ }^{20}$ Muhamed T. Osman and others, 'The New Miracle of Habbatus Sauda: Its Major Component Thymoquinone Can Be Used in the Management of Autoimmune Diseases', Procedia - Social and Behavioral Sciences, 121 (2014), 304-14 https://doi.org/10.1016/j.sbspro.2014.01.1131 
Even though they have been mingled with other components, the source can still be understood for items with experiential qualities, namely products that have been processed but the origin and authenticity are still known and have not been mixed with other ingredients. The origin of vegetable products, such as flour manufactured from rice, is still known and hasn't been mingled with other raw materials. It's also known as guava, which is processed into candied guava or salad with other ingredients, although its origin is unknown. Even if it has been blended with other ingredients, the origins and authenticity of animal products such as cut meat, fried chicken (meat), roasted, and so on are still known. Consumers can determine the halal status of products like this after purchasing and consuming them. Consumers' experiences with these items play an important role in determining their halal status, such as the flavor and texture of the product after eating. ${ }^{21}$

It turns out that there are issues and questions about animal slaughter when it comes to animal products with experiential features. Can customers solely use taste and experience to assess, evaluate, and validate the halalness of slaughtered animal products? As a result, the author believes that: (1) As long as the consumer "sees" the slaughtering process and confirms the slaughter's halalness, it includes search features since direct observation includes testing prior to purchase. (2) It is an experience characteristic if the consumer only "knows and knows" the butcher (old customer) and believes the slaughter is halal, because the consumer only relies on knowledge and acquaintance with the butcher, and this is included in the experience until consumers are informed that the slaughter is not halal. (3) It is a credence characteristic if the consumer does not watch the slaughtering procedure, does not know and recognize the slaughterer, and merely entrusts the halal slaughter to the slaughterer. Because consumers only trust the slaughterer with the technique and halal slaughter. ${ }^{22}$

It is a credibility factor because the origin and authenticity can be proven, but the halalness of the slaughter cannot. Consumers can assess merchants from the beginning of the killing and processing of animal products if they follow and observe them from the slaughtering, acquisition, and processing of animal products into, for example, fried or grilled chicken. Consumers who observe the processing of animal products from the beginning of slaughter do not know and recognize the slaughterer, and only entrust the halal slaughter to the slaughterer,

${ }^{21}$ Norazlina Abdul Aziz, Irini Ibrahim, and Nurazlina Abdul Raof, 'The Need for Legal Intervention within the Halal Pharmaceutical Industry', Procedia - Social and Behavioral Sciences, 121.September 2012 (2014), 124-32 https://doi.org/10.1016/j.sbspro.2014.01.1114

${ }^{22 N}$ Nursabrina Munawar and Hajah Makiah Tussaripah bt $\mathrm{Hj}$ Jamil, 'The Islamic Perspective Approach on Plant Pigments as Natural Food Colourants', Procedia - Social and Behavioral Sciences, 121 (2014), 193-203 https://doi.org/10.1016/j.sbspro.2014.01.1120 
which is a credence feature. Because only the method and halal slaughter are paid for by the consumer. ${ }^{23}$

The raw materials are with certainty for products with credence characteristics, namely products that have been fully processed without further knowledge of the origin and validity of the contents. In addition, various substances have been added to the product. ${ }^{24}$

In-plant products, for example, have been processed into various types of goods and mixed with other ingredients, depending on the provenance of the original components. For example, bread prepared with rice and other ingredients such as sugar, yeast, fat, milk, butter, and so on. Also, guava juice, which is produced from guava and contains sugar, soda, mineral water, and other components. Animal products, which have been processed into various sorts of goods from the source of other ingredients and mixed with other ingredients, are the same. The meat in the product can be beef, mutton, or chicken, similar to nuggets or meatballs prepared from raw meat and blended with other ingredients. Consumers cannot test and evaluate the halalness of such items because they lack the technical expertise to do so, especially for credence products created from animal raw materials, which can be in the form of halal or haram animals. ${ }^{25}$

Consumers will surely be harmed by items with promises of experience and credibility characteristics, because consumers will know or not know about the halalness of the product after purchasing and using it. Economically, the consumer has lost money, and religiously, the consumer has consumed haram food, which indicates that if the goods being exchanged is actually haram, the consumer has lost benefits. Consumers, of course, require reliable information on items that make claims about their experience and credibility. Consumers rely on certification and labeling for product identification, consumer information, and product marketing to recognize differences in the content of food goods. ${ }^{26}$

Of course, certification and labeling serve to ensure that the products traded do not create information gaps or mislead consumers. Similarly, halal certification and product labeling are communication tools that give consumers with knowledge and instruments to track product halalness and ensure that traded

${ }^{23}$ Ben Roy Do and Alaleh Dadvari, 'The Influence of the Dark Triad on the Relationship between Entrepreneurial Attitude Orientation and Entrepreneurial Intention: A Study among Students in Taiwan University', Asia Pacific Management Review, 22.4 (2017), 185-91 https://doi.org/10.1016/j.apmrv.2017.07.011

${ }^{24}$ Rajendran Muthuveloo, Narendran Shanmugam, and Ai Ping Teoh, 'The Impact of Tacit Knowledge Management on Organizational Performance: Evidence from Malaysia', Asia Pacific Management Review, 22.4 (2017), 192-201 https://doi.org/10.1016/j.apmrv.2017.07.010

25Panayuth Choeybal and Andrew Paterson, 'The Experience of Students Who Attended the UDRU - SMSU Development Program in Minnesota (United States)', Procedia - Social and Behavioral Sciences, 88 (2013), 328-33 https://doi.org/10.1016/j.sbspro.2013.08.513

${ }^{26}$ Naengnoi Yanwaree, 'The Effect of Using Learning Activities Based on PATH Method in Sexuality and Health Subject', Procedia - Social and Behavioral Sciences, 88 (2013), 225-28 https://doi.org/10.1016/j.sbspro.2013.08.500 
items do not deceive them. More fundamentally, product certification and labeling serve to shift consumers' perceptions of products from experience characteristics to search characteristics, and from credence characteristics to explore features, allowing them to select products based on their preferences and based on honest and credible information, resulting in a fair market. ${ }^{27}$

According to this theory, after halal certification and halal labeling on food products, consumers will be able to determine the halalness of the product based on experience characteristics that can be evaluated after purchase and consumption, as experience characteristics become search characteristics that consumers can validate through visible labels, and from credence characteristics that cannot be evaluated. For items with characteristic credence claims, government action, regulation, intervention, and market policy are all critically needed. Because customers solely rely on brands and labels to determine product quality as a credential signal to manufacturers, consumers cannot review, authenticate, or test the halalness of items even after they have consumed them. Mislabeled credibility, on the other hand, will diminish consumer trust in the product. $^{28}$

The problem is that halal items include qualities that cannot be directly evaluated and validated by consumers, even after they have used them. In these circumstances, a credible and trustworthy mechanism is required to monitor the distribution of items that rely on consumer confidence (credibility feature) to producers. As a result, it is evident that the state plays an important role in ensuring fair trade, especially to protect consumers from producer fraud because products are intended for personal use. Consumers must be safeguarded against becoming victims of these items. Consumers can confirm items through preliminary investigations before purchasing them, and not all product qualities require government intervention. Because consumers may inspect things before purchasing, third-party intervention (including the state) is practically unneeded. Consumers can make mistakes when it comes to products having experience features (adverse selection). This occurs when buyers are unable to detect the nature of a product before purchasing it since the information is only available to vendors. Several strategies that require only modest government intervention can usually be used to alleviate this issue. ${ }^{29}$

27Sirima Pinyoanuntapong, 'The Development of Thai Early Childhood Education Curriculum to Promote Desirable Characteristics of Preschool Children', Procedia - Social and Behavioral Sciences, 88 (2013), 321-27 https://doi.org/10.1016/j.sbspro.2013.08.512

28Shazlinda Md Yusof and Noriyuki Shutto, 'The Development of Halal Food Market in Japan: An Exploratory Study', Procedia - Social and Behavioral Sciences, 121.September 2012 (2014), 253-61 https://doi.org/10.1016/j.sbspro.2014.01.1126

${ }^{29}$ Zainor Nasrah Abdul Rahman and Siti Khadijah Ab Manan, 'Tawarruq as a Useful Instrument to Finance Retail the Halal Way', Procedia - Social and Behavioral Sciences, 121.September 2012 (2014), 281-90 https://doi.org/10.1016/j.sbspro.2014.01.1129 


\subsection{Reconstruction of Halal Product Assurance in the Pharmaceutical Sector in Indonesia}

The public needs to be efficiently and professionally informed about Halal (Halal and Suitable) theology, as well as competent counsel and infrastructure. Establishing an established, central, humanist, progressive, accommodating, and non-discriminatory legal institution, namely the legislation on guaranteeing Halal products, is one of the necessary measures to safeguard the Halal concept. In the Qur'an, the term "Halal" refers to both Halal in its core, i.e. food that is not forbidden, and Halal in terms of how to obtain it. Meanwhile, "thayyib" refers to food that is nutritious and does not hurt the body or mind. ${ }^{30}$

Various existing laws and regulations that regulate and relate to halal products do not provide legal certainty and legal guarantees for Muslim consumers to be able to consume or deliver legal warranties for halal products using halal products - are among the factors that are considered necessary for implementing the law on halal product guarantees. This scenario makes it difficult for individuals to tell the difference between halal and haram, causing physical discomfort and inner distress when they consume or use the product. Only the halalness of products, including as food, beverages, pharmaceuticals, cosmetics, biological chemical products, and genetic engineering, is regulated by the laws and regulations. ${ }^{31}$

Second, there is little legal certainty as to which institutions reflect the government's involvement in halal food certification. The current system does not ensure authority, responsibilities, or functions related to Halal product certification, including coordination. In legal theory, the fatwa of the Indonesian Ulema Council is still debatable as to its legal status, and the current system has failed to find a solution for how to make the fatwa of the Indonesian Ulema Council a national law and include it in the national legal instrument. ${ }^{32}$

Third, increased food technology, genetic engineering, biotechnology, and biological chemical processes are making it more difficult to govern product production and distribution in the home market. Fourth, the Indonesian halal product system does not yet have official halal standards and signs (Indonesian Halal Standards) set by the government, as is the case in Singapore, Malaysia, and the United States, and the perpetrators set their halal sign according to their own tastes, resulting in a variety of Halal sign counterfeiting that is difficult to combat. Fifth, the Halal product information system, which serves as a guide for business actors and the general public, is insufficient and does not reflect the

${ }^{30}$ Nurulhuda Noordin, Nor Laila Md Noor, and Zainal Samicho, 'Strategic Approach to Halal Certification System: An Ecosystem Perspective', Procedia - Social and Behavioral Sciences, 121.September 2012 (2014), 79-95 https://doi.org/10.1016/j.sbspro.2014.01.1110

${ }^{31}$ Aziz and Sulaiman.

${ }^{32}$ Resti Dian Luthviati, 'The Role of Local Governments in the Defense of Leading Products Resti', Jurnal Bestuur, 8.2 (2020), 121-28 https://doi.org/10.20961/bestuur.43138 
current state of knowledge and public demand for Halal products. ${ }^{33}$

Halal product assurance incorporates the concept of halal products consumed or used by Muslim consumers in accordance with Islamic law into material and ceremonial law in national law. The raw ingredients utilized in product processing, product processing, and product packaging all fall under the halal category. This regulation covers a wide range of raw materials and products, including food, beverages, medicines, cosmetics, biological chemical products, and genetic engineering. As a halal product, the production equipment, storage, packaging, distribution, and presentation in the production process must be segregated from pig-based materials and contain pork and other designated criminal elements, according to the Halal product guarantee law. The Halal Product Guarantee Law, in particular, demands that the production location for halal processed materials be kept apart from the production location for pork processed components or containing pork elements. ${ }^{34}$

All things consumed by society, particularly those conforming to Islamic law, require legal protection from the government. As a result, the Halal Product Guarantee Law is important and necessary in order to meet the needs of the Muslim community in terms of legal guarantees for lawful production and consumption. Because halal food must also be thoyyiban in Islam, thoyyib can refer to the nutritional content of the food ingested as well as the processing procedure, both of which must follow food science and nutrition guidelines. Halal certification is a requirement that cannot be waived. The existence of halal product protection and legal certainty benefits not only the community, but also the state administration in carrying out its responsibilities. Various laws and regulations relating to the rule of halal products have not offered legal clarity and guarantees for the Muslim community, according to the Halal Product Guarantee Act and general explanations. ${ }^{35}$

It is also stated that the halalness of a product is determined based on the Fatwa of the Indonesian Ulema Council and the results of the halal inspection agency's inspection and testing in the form of a halal certificate registered by the Minister. Halal certificates and seals provide customer protection from a variety of products that are not regarded Shari'a compliant, which is especially important in Indonesia, which has a Muslim majority, and can become a competitive advantage. The certification and inclusion of the halal label of a new

33Senee Suwandee, Vipavee Anupunpisit, and Piyanan Boonpen, 'Quality of Life and Environment of Communities Along Saen Saeb Canal: A Guideline for Reform (Phase II)', Procedia - Social and Behavioral Sciences, 88 (2013), 212-19 https://doi.org/10.1016/j.sbspro.2013.08.498

${ }^{34}$ Maher A.A. Abdelsamie, Russly Abdul Rahman, and Shuhaimi Mustafa, 'Pyramid Shape Power as a New Halal-Compliant Food Preservation and Packaging Technique', Procedia - Social $\begin{array}{lllll}\text { and Behavioral } \quad \text { Sciences, } & \text { 121.September } & 2012 & \text { 232-42 }\end{array}$ https://doi.org/10.1016/j.sbspro.2014.01.1124

${ }^{35}$ Nuanthip Kaewsri and Tanit Tongthong, 'Professional Development of Female Engineers in the Thai Construction Industry', Procedia - Social and Behavioral Sciences, 88 (2013), 291-98 https://doi.org/10.1016/j.sbspro.2013.08.508 
product has touched a small number of Indonesian producers, based on facts about the distribution of food and beverages in Indonesia. ${ }^{36}$

In Indonesia, halal problems are a contentious topic that has drawn the attention of the international community. Halal characteristics of food, beverage, medication, and cosmetic items, as well as biological chemical processes and genetic engineering, are important to Muslim customers. ${ }^{37}$ The product in question necessitates a normative reaction from the government in order to protect citizens' fundamental rights under the 1945 Constitution and Pancasila. ${ }^{38}$

Table 1

Halal Certification in Indonesia 2013-2020

\begin{tabular}{|c|c|c|c|c|}
\hline Year & Company total & $\begin{array}{l}\text { Halal } \\
\text { Total }\end{array}$ & Certificate & Product Total \\
\hline 2013 & 4,325 & 4,869 & & 39,002 \\
\hline 2014 & 5,829 & 6,157 & & 32,890 \\
\hline 2015 & 6,666 & 7,014 & & 64,121 \\
\hline 2016 & 10,180 & 10,322 & & 68,576 \\
\hline 2017 & 7,940 & 8,676 & & 77,256 \\
\hline 2018 & 6,564 & 7,392 & & 114,264 \\
\hline 2019 & 7,198 & 8,157 & & 127,286 \\
\hline 2020 & 11,249 & 17,398 & & 204,222 \\
\hline Total (2013- 2020) & 59,951 & 69,985 & & 727,617 \\
\hline
\end{tabular}

Sourche: Indonesian Council of Ulama, 2020.

Indonesia is becoming increasingly clogged with imported products suspected of containing illegal ingredients or raw materials in the era of regional and international free trade. This is because many preservatives that risk health or additives that contain haram substances prohibited by sharia are used in processing, storage, and packing processes. Halal certification and marking have gotten a lot of attention in the international trade system as a way to safeguard customers all over the globe and as a strategy to deal with the issues of globalization of product marketing. In terms of certification and labeling management, several countries are compared: 1) Malaysia is a federal state with Islam as the federation's official religion. Malaysia's halal certification and labeling

36 Abdul Raufu Ambali and Ahmad Naqiyuddin Bakar, 'People's Awareness on Halal Foods and Products: Potential Issues for Policy-Makers', Procedia - Social and Behavioral Sciences, 121.September 2012 (2014), 3-25 https://doi.org/10.1016/j.sbspro.2014.01.1104

${ }^{37}$ KN Sofyan Hasan, 'Kepastian Hukum Sertifikasi Dan Labelisasi Halal Produk Pangan', Jurnal Dinamika Hukum, 14.2 (2014), 227-38 https://doi.org/10.20884/1.jdh.2014.14.2.292

38 Cheng Nan Chen, Shieunt-HanTsai, and Arnold Japutra, 'Introduction to the Special Issue on Entrepreneurship and Management in Turbulent Global Environment', Asia Pacific Management Review, 22.4 (2017), 167 https://doi.org/10.1016/j.apmrv.2017.11.003 
is important to investigate since it examines direct management in an Islamic country as well as Indonesia's neighbor. 2) Even though Singapore is a secular democracy that supports religious freedom, it constitutionally accommodates the existence of the Islamic religion by allowing the Islamic Council to advise the president. Singapore, as well as Indonesia's neighbor, is deemed relevant as a comparison for this research in terms of the religion of Islam. ${ }^{39}$

\section{Conclusion}

Based on the results of the discussion in the previous chapter, it can be concluded that the author is as follows; firstly, the halal product guarantee law does not yet provide legal certainty regarding the product to determine the halal product guarantee certificate for the product. This is the legal basis for regulations that provide legal certainty for guaranteeing halal products. In addition, this provision, with all its shortcomings, which only regulates food matters, does not necessarily restrict drugs, cosmetics, biological chemical products, and genetic engineering. Moreover, slaughter products follow the sharia corridor, as stipulated in the main provisions on animal husbandry and health. Secondly, consumers have the right to comfort, security, and safety in consuming goods or services. This means that every consumer in Indonesia has the right to get comfortable goods because it does not conflict with the rules of his religion so that it can be consumed. Consumers are also entitled to correct, transparent and honest information regarding product conditions and guarantees. To overcome this very fundamental problem of the people, it cannot be done partially, let alone individually. All links involved in the drug production process, from manufacturers, pharmacies, pharmacists, doctors, governments, MUI, drug and vaccine businesses, and scientists, including universities, must sit together in one forum to provide solutions to this big problem. So that Muslim consumers can use the drugs they need with a peaceful heart because they are not worried about the halal status of their medications.

\section{References}

Abdul Raufu Ambali and Ahmad Naqiyuddin Bakar, 'People's Awareness on Halal Foods and Products: Potential Issues for Policy-Makers', Procedia Social and Behavioral Sciences, 121.September 2012 (2014), 3-25 https://doi.org/10.1016/j.sbspro.2014.01.1104

Aiedah Abdul Khalek, 'Young Consumers' Attitude towards Halal Food Outlets and JAKIM's Halal Certification in Malaysia', Procedia - Social and Behavioral

39 Ismah Osman and others, 'Family Food Consumption: Desire towards Convenient Food Products', Procedia - Social and Behavioral Sciences, 121.September 2012 (2014), 223-31 https://doi.org/10.1016/j.sbspro.2014.01.1123 
Sciences, $\quad$ 121.September $2012 \quad$ (2014), 26-34 https://doi.org/10.1016/j.sbspro.2014.01.1105

Ben Roy Do and Alaleh Dadvari, 'The Influence of the Dark Triad on the Relationship between Entrepreneurial Attitude Orientation and Entrepreneurial Intention: A Study among Students in Taiwan University', Asia Pacific Management Review, $22.4 \quad$ (2017), 185-91 https://doi.org/10.1016/j.apmrv.2017.07.011

Chaisak Chitcharoen and others, 'A Model to Investigate the Influence of Channel, Perceived Web Quality, Brand Awareness, Perceived Quality on After-Sales Service of the All-in-One Office Products', Procedia - Social and Behavioral Sciences, 88 (2013), 8-12 https://doi.org/10.1016/j.sbspro.2013.08.475

Cheng Nan Chen, Shieunt-HanTsai, and Arnold Japutra, 'Introduction to the Special Issue on Entrepreneurship and Management in Turbulent Global Environment', Asia Pacific Management Review, 22.4 (2017), 167 https://doi.org/10.1016/j.apmrv.2017.11.003

Chiratus Ratanamaneichat and others, 'A Guideline for Reinforcing Water Based Community's Economic Strength', Procedia - Social and Behavioral Sciences, 88 (2013), 173-78 https://doi.org/10.1016/j.sbspro.2013.08.493

Dwi Edi Wibowo, 'Ewuh Pakewuh Cultural Reconstruction to Equal Consumer

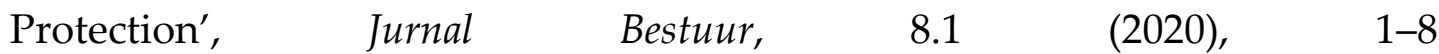
$<$ https://doi.org/10.20961/bestuur.41395>.

Haslizatul Mohamed Hanum and others, 'Using Topic Analysis for Querying Halal Information on Malay Documents', Procedia - Social and Behavioral Sciences, $\quad$ 121.September $2012 \quad$ (2014), 214-22 https://doi.org/10.1016/j.sbspro.2014.01.1122

Ismah Osman and others, 'Family Food Consumption: Desire towards Convenient Food Products', Procedia - Social and Behavioral Sciences, 121.September 2012 (2014), 223-31 https://doi.org/10.1016/j.sbspro.2014.01.1123

KN Sofyan Hasan, 'Kepastian Hukum Sertifikasi Dan Labelisasi Halal Produk Pangan', Jurnal Dinamika Hukum, $14.2 \quad$ (2014), 227-38 https://doi.org/10.20884/1.jdh.2014.14.2.292

Lego Karjoko, Zaidah Nur Rosidah, and I. Gusti Ayu Kutut Rachmi Handayani, 'Refleksi Paradigma Ilmu Pengetahuan Bagi Pembangunan Hukum $\begin{array}{lllll}\text { Pengadaan Tanah Lego', } & \text { Bestuur, } & 7.2 & \text { (2019), 14 }\end{array}$ https://doi.org/https://doi.org/10.20961/bestuur.v7i1.42694

Liana Endah Susanti, 'Economic Law Creation Beautiful Global Indonesia', Bestuur, 7.1 (2020), 47 https://doi.org/10.20961/bestuur.v7i1.42701

Maher A.A. Abdelsamie, Russly Abdul Rahman, and Shuhaimi Mustafa, 'Pyramid Shape Power as a New Halal-Compliant Food Preservation and Packaging Technique', Procedia - Social and Behavioral Sciences, 121.September 2012 (2014), 232-42 https://doi.org/10.1016/j.sbspro.2014.01.1124

Muhamed T. Osman and others, 'The New Miracle of Habbatus Sauda: Its Major Component Thymoquinone Can Be Used in the Management of 
Autoimmune Diseases', Procedia - Social and Behavioral Sciences, 121 (2014), 304-14 https://doi.org/10.1016/j.sbspro.2014.01.1131

Naengnoi Yanwaree, 'The Effect of Using Learning Activities Based on PATH Method in Sexuality and Health Subject', Procedia - Social and Behavioral Sciences, 88 (2013), 225-28 https://doi.org/10.1016/j.sbspro.2013.08.500

Najella Zubaidi, Regy Gusti Pratama, and Sholahuddin Al-Fatih, 'Legal Perspective on Effectiveness of Pre-Work Cards for Indonesian People', Bestuur, 8.1 (2020), 9 https://doi.org/10.20961/bestuur.v8i1.42722

Norazlina Abdul Aziz and Siti Sarah Sulaiman, 'Role of the Local Authority in Issuing License for Halal Certified Premise in the City of Shah Alam', Procedia - Social and Behavioral Sciences, 121.September 2012 (2014), 133-43 https://doi.org/10.1016/j.sbspro.2014.01.1115

Norazlina Abdul Aziz, Irini Ibrahim, and Nurazlina Abdul Raof, 'The Need for Legal Intervention within the Halal Pharmaceutical Industry', Procedia Social and Behavioral Sciences, 121.September 2012 (2014), 124-32 https://doi.org/10.1016/j.sbspro.2014.01.1114

Nuanthip Kaewsri and Tanit Tongthong, 'Professional Development of Female Engineers in the Thai Construction Industry', Procedia - Social and Behavioral Sciences, 88 (2013), 291-98 https://doi.org/10.1016/j.sbspro.2013.08.508

Nurfaika Ishak, Rahmad Ramadhan Hasibuan, and Tri Suhendra Arbani, 'Bureaucratic and Political Collaboration Towards a Good Governance System', Bestuur, 8.1 (2020), 19 https://doi.org/10.20961/bestuur.v8i1.42922

Nursabrina Munawar and Hajah Makiah Tussaripah bt Hj Jamil, 'The Islamic Perspective Approach on Plant Pigments as Natural Food Colourants', Procedia - Social and Behavioral Sciences, 121 (2014), 193-203 https://doi.org/10.1016/j.sbspro.2014.01.1120

Nurulhuda Noordin, Nor Laila Md Noor, and Zainal Samicho, 'Strategic Approach to Halal Certification System: An Ecosystem Perspective', Procedia - Social and Behavioral Sciences, 121.September 2012 (2014), 79-95 https://doi.org/10.1016/j.sbspro.2014.01.1110

Panayuth Choeybal and Andrew Paterson, 'The Experience of Students Who Attended the UDRU - SMSU Development Program in Minnesota (United States)', Procedia - Social and Behavioral Sciences, 88 (2013), 328-33 https://doi.org/10.1016/j.sbspro.2013.08.513

Pattawan Narjaikaew, 'Alternative Conceptions of Primary School Teachers of Science about Force and Motion', Procedia - Social and Behavioral Sciences, 88 (2013), 250-57 https://doi.org/10.1016/j.sbspro.2013.08.503

Penpak Chauyraksa, 'The Satisfaction on General Affairs Service of Electrical Engineering Faculty of Industrial and Technology, Rajamangala University of Technology Isan', Procedia - Social and Behavioral Sciences, 88 (2013), 149-53 https://doi.org/10.1016/j.sbspro.2013.08.490

Rajendran Muthuveloo, Narendran Shanmugam, and Ai Ping Teoh, 'The Impact of Tacit Knowledge Management on Organizational Performance: Evidence 
from Malaysia', Asia Pacific Management Review, 22.4 (2017), 192-201 https://doi.org/10.1016/j.apmrv.2017.07.010

Resti Dian Luthviati, 'The Role of Local Governments in the Defense of Leading

Products Resti', Jurnal Bestuur, 8.2 (2020), 121-28

https://doi.org/10.20961/bestuur.43138

Senee Suwandee, Vipavee Anupunpisit, and Piyanan Boonpen, 'Quality of Life and Environment of Communities Along Saen Saeb Canal: A Guideline for Reform (Phase II)', Procedia - Social and Behavioral Sciences, 88 (2013), 212-19 https://doi.org/10.1016/j.sbspro.2013.08.498

Shazlinda Md Yusof and Noriyuki Shutto, 'The Development of Halal Food Market in Japan: An Exploratory Study', Procedia - Social and Behavioral Sciences, 121.September 2012 (2014), 253-61 https://doi.org/10.1016/j.sbspro.2014.01.1126

Sirima Pinyoanuntapong, 'The Development of Thai Early Childhood Education Curriculum to Promote Desirable Characteristics of Preschool Children', Procedia $\begin{array}{llll}\text { Social and Behavioral } & \text { Sciences, } 88 \text { (2013), }\end{array}$ https://doi.org/10.1016/j.sbspro.2013.08.512

Supatra Wanpen, 'The Relationship between Learning Styles and the Social Network Use of Tertiary Level Students', Procedia - Social and Behavioral Sciences, 88 (2013), 334-39 https://doi.org/10.1016/j.sbspro.2013.08.514

Tommy Shih and Yen Yu Huang, 'A Case Study on Technology Entrepreneurship Education at a Taiwanese Research University', Asia Pacific Management Review, 22.4 (2017), 202-11 https://doi.org/10.1016/j.apmrv.2017.07.009

Veeraphat Krittanathip and others, 'The Reduction of Inventory and Warehouse

Costs for Thai Traditional Wholesale Businesses of Consumer Products', Procedia - Social and Behavioral Sciences, 88 (2013), 142-48 https://doi.org/10.1016/j.sbspro.2013.08.489

Vloreen Nity Mathew, Ardiana Mazwa Raudah binti Amir Abdullah, and Siti Nurazizah binti Mohamad Ismail, 'Acceptance on Halal Food among NonMuslim Consumers', Procedia - Social and Behavioral Sciences, 121 (2014), 26271 https://doi.org/10.1016/j.sbspro.2014.01.1127

Wilma Taverne-Veldhuizen and others, 'Effect of Hydrogenation of Palm Oil Products Spiked with Octachlorodibenzo-p-Dioxin on Dioxin Congener Profiles and Toxic Equivalent Levels', Food Control, 132.August 2021 (2022), 108546 https://doi.org/10.1016/j.foodcont.2021.108546

Zaidah Nur Rosidah, 'Coherence of the Rules of Sharia Against Pancasila', Bestuur, 8.1 (2020), 40 https://doi.org/10.20961/bestuur.v8i1.42723

Zainor Nasrah Abdul Rahman and Siti Khadijah Ab Manan, 'Tawarruq as a Useful Instrument to Finance Retail the Halal Way', Procedia - Social and Behavioral Sciences, $\quad$ 121.September $2012 \quad$ (2014), 281-90 https://doi.org/10.1016/j.sbspro.2014.01.1129

Zakiah Samori and Noorsalwati Sabtu, 'Developing Halal Standard for Malaysian Hotel Industry: An Exploratory Study', Procedia - Social and Behavioral Sciences, $\quad 2012$ https://doi.org/10.1016/j.sbspro.2014.01.1116 